\title{
A method of detecting chemical union of metals
}

\section{Dr. G. Gore F.R.S.}

To cite this article: Dr. G. Gore F.R.S. (1890) A method of detecting chemical union of metals, Philosophical Magazine Series 5, 30:183, 202-203, DOI: 10.1080/14786449008621379

To link to this article: http://dx.doi.org/10.1080/14786449008621379

曲 Published online: 08 May 2009.

Submit your article to this journal

Џll Article views: 2

Q View related articles $₫$ 


\section{A METHOD OF DETECTING CHEMICAL UNION OF METALS.} BY DR. G. GORE, F.R.S.

It is well known that evolntion of heat during the mixing of two substances is a sign of chemical union; that considerable heat is evolved during the melting together of certain metals, for instance zinc and platinum; and M. J. Regnauld has shown that whilst zinc, during its amalgamation by mercury, absorbs heat and becomes more electropositive, cadmium by amalgamation evolves heat and becomes less electropositive (Comptes Rendus Acad. Sci. June 10, 1878; Chemical News, vol, xxxviii. p. 33).

Having aiready found in a large number of instances that the chemical union of two soluble substances, such as halogens, acids, salts, \&c., night be detected by the depression of voltaic energy which occurs when the two dissolved substances are in the proportions of their ordinary chemical equivalents (see Proc. Roy. Soc. vol, xlv. p. 265 ; "Examples of Solution-compounds," Proc. Birm. Phil. Soc. vol. vii. p. 33 ; Chemical News, 1890, vol. Ixi. p. 172), I have adopted a similar method in this case, and bave made a series of experiments to ascertain the relative amounts of voltaic energy in a one-per-cent. aqueous solution of common salt, of a series of amalgams composed of different proportions of cadmium and mercury, and observed whether there was a distinct depression of that energy indicating chemical union, when the particular amalgam composed of equivalent weights of the two metals was employed.

As I had previously found that the amalgam changed in electromotive force spontaneously, in order to balance this influence, I employed, instead of a voltaic couple composed of platinum and one bar of a series of bars of different composition, a couple composed of a bar of fixed composition formed of the two metals in the proportions of their equivalent weights, and one bar of a series of bars of different composition. The two bars in each experiment were connected with an ordinary torsion-galvanometer of $50 \mathrm{ohms}$ resistance, and the amount of permanent deflexion of the needles after about half a minute was recorded. This method was found sufficiently sensitive for the purpose. The composition of the bars of yaried composition is shown below by the chemical formula.

After some preliminary experiments, the results of which agreed with those given, the following series was made:-

\begin{tabular}{|c|c|c|}
\hline & oits & couple. \\
\hline $\mathrm{CdI}$ & wi & $\mathrm{Cd}$ \\
\hline " & $"$ & $\mathrm{Cd}_{17} \mathrm{Hg}_{10}$ \\
\hline , & " & $\mathrm{Cd}_{15} \mathrm{Hg}_{10}$ \\
\hline " & $"$ & $\mathrm{Hg}_{10}$ \\
\hline ", & $"$ & $\lg _{10}$ \\
\hline '2 & ", & $g_{10}$ \\
\hline " & " & $\mathrm{Hg}_{12}$ \\
\hline " & " & $\mathrm{Cd}_{10} \mathrm{Hg}_{13}$ \\
\hline " & $"$ & $\mathrm{Hgg}_{15}$ \\
\hline " & $"$ & 82 \\
\hline , & "9 & \\
\hline
\end{tabular}

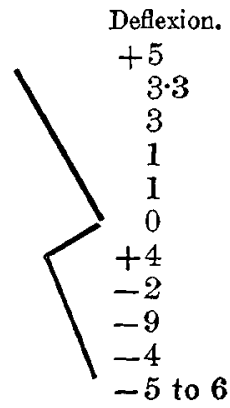


As the amounts of deflexion varied with different parts of the surface of the same bar, the surfaces of the bars were scraped quite clean and the experiments with the amalgams $\mathrm{Cd}_{12} \mathrm{Hg}_{10}, \mathrm{Cd}_{10} \mathrm{Hg} \mathrm{g}_{10}$, and $\mathrm{Cd}_{10} \mathrm{Hg}_{12}$ repeated; the same numbers as given above were obtained.

The numbers obtained in each case show a distinct depression of strength of current with the amalgam composed of equivalent weights of the two metals, similar to that obtained with halogens, acids, and salts, and indicate that the two metals chemically unite together in the proportions of their ordinary chemical equivalents. The method may therefore probably be employed for the pupose of detecting the chemical union of metals.

ON THE SPECTRA OF THE ALKALIES.

BY PROF. H. KAYSER AND PROF. C. RUNGE.

The investigation of the spectra of the alkalies has led us to results which we present in the following short abstract.

The spectra of the alkalies are formed in an entirely analogous manner, which is especially manifest if, instead of the wave-lengths, we consider the reciprocals-that is, the numbers of vibrations. Each spectra is seen to be made up of sereral series of lines, each of which may be represented with great accuracy by the formula

$$
\frac{1}{\lambda}=\mathrm{A}-\frac{\mathrm{B}}{n^{2}}-\frac{\mathrm{C}}{n^{4}}
$$

where $\lambda$ is the wave-length, $\mathrm{A}, \mathrm{B}$, and $\mathrm{C}$ are three constants, and $n$ stands for the series of whole numbers from $n=3$ upwards. For $n=2$ the formulæ give in all cases negative-that is, impossible numbers of vibrations; $n=3$ represents the fundamental vibrations.

The lines of the various series of each element behave very differently as regards visibility, widening out with increase of vapour-density. In each element we find one chief series which contains the strongest lines, those which appear most easily, and those which are most easily reversible; it extends in all cases from the red end of the spectrum to the extreme ultra-violet. The members of the principal series, with the exception of lithium, are with all alkalies pairs, whose distance is less as the wave-length increases; we have found that the difference of the numbers of vibrations for the two lines of each pair is inversely proportional to the number of this pair, that is of the value $n$, which, when inserted in the formula, gives the pair.

Besides the chief series, all alkalies have accessory series which essentially appear in the visible part of the spectrum. In lithium there are two secondary series, and in sodium four, each two of 